\title{
Uji Organoleptik Tepung Ampas Tahu Dengan Variasi Lama Pengeringan
}

\author{
Yuniarti DR ${ }^{1 *}$, Akhmad Solikhin ${ }^{2}$, Melly Fera ${ }^{3}$ \\ ${ }^{1}$ Prodi Ilmu Gizi, Fakultas Ilmu Kesehatan, Universitas Muhadi Setiabudi Brebes, Indonesia \\ 2 Prodi Ilmu dan Teknologi Pangan, Fakultas Sains dan Teknologi, Universitas Muhadi Setiabudi \\ Brebes, Indonesia \\ e-mail: ${ }^{1}$ yuniartidewi.rahmawati@gmail.com
}

\begin{abstract}
ABSTRAK
Penelitian pembuatan tepung ampas tahu bertujuan untuk mengurangi limbah pengolahan tahu sehingga menjadi bahan yang lebih berdaya guna Metode penelitian menggunakan Rancangan Acak Lengkap $(R A L)$ yang terdiri 5 (lima) perlakuan 15, 30, 45, 60, 75, dan 90 menit dengan diulang sebanyak 3 (tiga) kali. Pengujian data penelitian meliputi uji organoleptik. Data hasil pengujian dianalisis menggunakan analasis sidik ragam atau ANOVA dan uji lanjut Duncan,s Multiple Range Test (DMRT). Hasil penelitian uji organoleptik warna menunjukkan berpengaruh nyata dengan P6 sebagai perlakuan ideal menghasilkan warna putih kekuningan. Hasil uji organoleptik bau berpengaruh nyata dan tepung yang dihasilkan tidak berbau dengan lama 90 menit proses pengeringan. Hasil uji organoleptik rasa berpengaruh nyata dan tepung yang dihasilkan memiliki rasa khas ampas tahu. Hasil uji organoleptik tekstur berpengaruh nyata dan tepung yang dihasilkan memiliki tekstur tidak menggumpal dan halus.
\end{abstract}

Kata kunci: Tepung, Ampas Tahu, Lama Pengeringan

\begin{abstract}
Research on making pulp flour know aims to reduce the waste processing tofu so that it becomes a more empowered material for the research method using complete random draft (RAL) consisting of 5 (five) treatments 15, 30, 45, 60, 75, and 90 minutes with repeated 3 (three) times. Testing of research data includes organoleptic test. The test result Data is analyzed using variegated or ANOVA analytes and further tests of Duncan,s Multiple Range Test (DMRT). The results of the color organoleptic test show a noticeable effect with P6 as the ideal treatment produces a yellowish white color. The results of organoleptic test smell real effect and the resulting flour does not smell with the old 90 minutes of drying process. The result of organoleptic test is a real effect and the flour produced has a distinctive flavor of tofu. The results of organoleptic test of the texture are real and the resulting flour has a not agglomerate and smooth texture.

Key words: flour, tofu, drying time
\end{abstract}

\section{PENDAHULUAN}

Tahu merupakan olahan yang banyak digemari masyarakat karena selain harganya murah tahu juga berperan sebagai sumber protein nabati pengganti makanan protein hewani[1]. Kandungan gizi tahu dalam setiap 100gram terdapat energi 86 kkal dan 7,8 protein[2]. Proses pembuatan tahu biasanya menghasilkan limbah yang mencemari lingkungan. Limbah tersebut berupa cairan dan limbah dengan bentuk padat yang disebut juga ampas tahu. Ampas tahu bersifat mudah rusak dan tidak tahan lama selain itu mempunyai nilai ekonomi yang rendah. Masyarakat di daerah-daerah pada umumnya memanfaatkan ampas tahu sebagai pakan ternak. Kandungan nutrisi dalam ampas tahu masihcukup tinggi dalam 100 gram mengandung karbohidrat $11,07 \%$, protein $4,71 \%$, lemak $1,94 \%$, dan abu $0,08 \%,[3]$.

Pemanfaatan ampas tahu masih kurang dilakukan oleh masyarakat sehingga limbah ampas tahu hanya dibuang. Untuk mengurangi limbah ampas tahu dilakukan pemanfaatan dengan mengubah limbah ampas tahu menjadi tepung dengan proses pengeringan. Ampas tahu yang sudah dibuat menjadi tepung memiliki daya simpan lebih panjang, mudah disimpan dan lebih variatif dalam pemanfaatannya. Kreasi tepung ampas tahu menjadi produk pangan yang enak, bergizi dan aman dikonsumsi, seperi kerupuk, stik, kue kering dan sebagainya[4]. 
Tepung ampas tahu merupakan hasil hancuran ampas tahu kering, kemudian dihaluskan dan diayak dengan tingkat kehalusan kurang lebih 80 mesh[5]. Pengolahan tepung ampas tahu dilakukan agar mempunyai sifat fungsional sehingga bahan akan mudah dilakukannya perancangan produk pangan baru[6]. Adapun kandungan gizi pada tepung ampas tahu seperti Tabel 1

Tabel 1. Komposisi Gizi Tepung Ampas Tahu (dalam 100 gr)

\begin{tabular}{cc}
\hline Komponen & Tepung Ampas Tahu Kering \\
\hline Serat Kasar & $3,23 \%$ \\
Protein & $17,72 \%$ \\
Lemak & $2,62 \%$ \\
Karbohidrat & $66,24 \%$ \\
\hline
\end{tabular}

Pemanfaatan ampas tahu diolah menjadi tepung ampas tahu berguna untuk subtitusi tepung lain dalam pembuatan produk olahan makanan baru, maka dari itu perlu adanya teknik pengeringan. Teknik pengeringan tepung ampas tahu dapat dilakukan dengan beberapa cara, seperti dengan bantuan sinar matahari, mesin spinner dan oven. Selain teknik pengeringan juga yang perlu diperhatikan yaitu lama proses pengeringan tepung ampas tahu. Lama proses pengeringan akan memberikan perubahan pada karakteristik tepung ampas tahu karena adanya perlakuan panas.

Pengeringan merupakan proses pengeluaran air dari dalam bahan, dan proses menggunakan panas untuk menghasilkan produk kering. Proses ini dipengaruhi oleh kondisi eksternal yaitu suhu, kelembaban, kecepatan dan tekanan udara panas. kondisi internal seperti kadar air, bentuk/geometri, luas permukaan dan keadaan fisik bahan. Dalam proses pengeringan apabila semakin tinggi suhu yang digunakan untuk pengeringan, makin tinggi energi yang disuplai dan makin cepat laju pengeringan. Akan tetapi pengeringan yang terlalu cepat akan merusak bahan karena permukaan bahan terlalu cepat kering sehingga tidak sebanding dengan perpindahan kecepatan air ke permukaan. Suhu yang tinggi dalam pengeringan juga dapat merusak struktur dan kandungan dari suatu bahan[7]. Selain suhu proses pengeringan juga dipengaruhi oleh tekanan udara. Semakin kecil tekanan udara yang dibutuhkan untuk pengeringan semakin besar kemampuan udara untuk mengangkut air selama pengeringan. Sebaliknya jika tekanan udara semakin besar maka udara yang disekitar pengeringan akan lembab, Sehingga kemampuan menampung uap air terbatas dan menghambat proses atau laju pengeringan [8].

\section{BAHAN DAN METODE}

Bahan utama yang dibutuhkan dalam penelitian ini adalah ampas tahu basah yang didapat langsung dari industry rumah tangga pembuatan tahu. Beberapa alat yang digunakan untuk pembuatan tepung ampas tahu diantaranya: oven, blender, cawan petri, nampan, ayakan mesh 80, alat pres, dan ember. Proses pembuatan tepung ampas tahu dapat dilihat pada gambar 1 .

Uji yang dilakukan terhadap hasil tepung ampas tahu adalah uji organoleptik. Pengolahan data pada penelitian ini menggunakan model Rancangan Acak Lengkap (RAL) terdiri dari 6 perlakuan dengan 3 kali ulangan sehingga 18 (delapan belas) kali percobaan. Data tersebut dianalisa menggunakan analisa keragaman. Bila hasil analisis ragam menunjukkan pengaruh nyata atau sangat nyata dilakukan Uji Lanjut Duncan's Multiple Range Test (DMRT) pada taraf $5 \%$ 


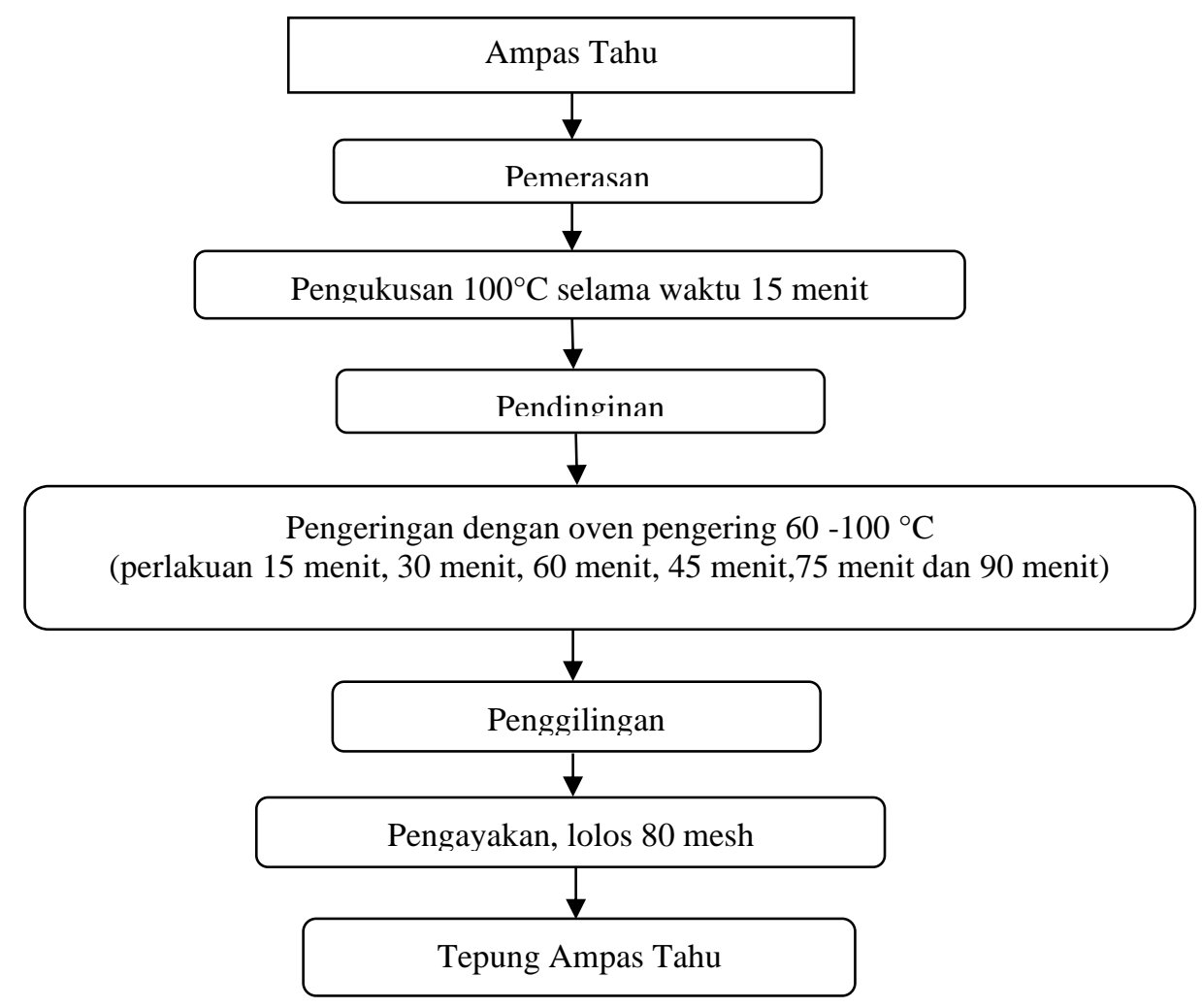

Gambar 1. Diagram alir proses pembuatan ampas tahu

HASIL DAN PEMBAHASAN

\section{Warna}

Uji organoleptik indikator warna dilakukan pada semua perlakuan (lama pengeringan) di mana P1 (15 menit), P2 (30 menit), P3 (45 menit), P4 (60 menit), P5 (75 menit) dan P6 (90 menit).Uji organoleptik pada warna produk makanan melalui indera penglihatan untuk mengenali dan membedakan warna produk tersebut.Berdasarkan hasil data penelitian pengujian organoleptik terhadap parameter warna dengan lama proses pengeringan tepung ampas tahu menunjukan bahwa hasil analisis sidik ragam (Anova) semua perlakuan memiliki pengaruh yang nyata, hal ini ditujukan pada nilai signifikansi lebih kecil dari 0,005 dan $\mathrm{F}_{\text {hitung }}(119,98)$ lebih besar dari $\mathrm{F}_{\text {tabel }}$ $(2,27)$ dengan tingkat kepercayaan $95 \%$.

Hasil uji organolpetik tepung ampas tahu dapat dilihat pada gambar 2 berikut :

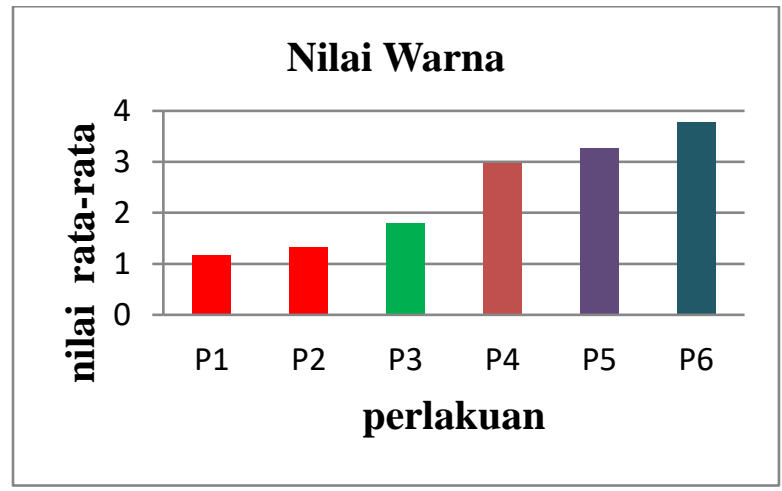

Gambar 2. Histogram hasil uji organoleptik warna 
Hasil uji lanjut parameter warna dapat dilihat pada table 2

Tabel 2. Hasil Uji Lanjut Parameter Warna

\begin{tabular}{ccc}
\hline Perlakuan & Nilai rata-rata & Kriteria \\
\hline P1 & $1,17^{\mathrm{a}}$ & Coklat kehitaman \\
P2 & $1,33^{\mathrm{a}}$ & Coklat kehitaman \\
P3 & $1,80^{\mathrm{b}}$ & Coklat gelap \\
P4 & $2,97^{\mathrm{c}}$ & Coklat \\
P5 & $3,27^{\mathrm{d}}$ & Coklat \\
P6 & $3,77^{\mathrm{e}}$ & Putih kekuningan \\
\hline
\end{tabular}

Keterangan: abc superkrip yang diikuti oleh huruf yang tidak sama menunjukan berbeda nyata. $(\mathrm{p}<0,05)$

Hasil uji organoleptik untuk parameter warna perlakuan P1 (skor 1,17) dan P2 (skor 1,33) menghasilkan warna yang tidak baik secara kenampakan, hal ini yang menyebabkan perlakuan P1 dan P2 tidak diterima oleh panelis. Menurut Andarwulan et al (2011) menyatakan bahwa produk yang warna dianggap menyimpang dari warna yang seharusnya, maka konsumen tidak tertarik lagi untuk memberikan penilaian yang baik[9]. Sedangkan pada perlakuan P6 (skor 3,77) menghasilkan warna putih kekuningan secara kenampakan. Pada perlakuan P6 menhasilkan nilai skor paling tinggi dari perlakuan lainya karena panelis menyukai warna tepung yang dihasilkan yaitu warna putih kekuningan. Perbedaan warna disebabkan pengaruh lama pengeringan sehingga warna tepung ampas tahu berubahSemakin lama pengeringan akan merubah warna tepung yang dihasilkan[10]. Pada penelitian ini selain lama pengeringan juga dipengaruhi bahan tepung yang dibuat yaitu ampas tahu yang berwarna putih kekuningan. Warna ampas tahu kering berwarna putih kekuningan[11].

\section{Bau}

Uji organoleptik indikator bau dilakukan pada semua perlakuan (lama pengeringan) di mana P1 (15 menit), P2 (30 menit), P3 (45 menit), P4 (60 menit), P5 (75 menit) dan P6 (90 menit). Uji organoleptik pada bau atau aroma produk makanan diamati melalui indera penciuman untuk mengenali dan membedakan aroma produk tersebut. Berdasarkan hasil data penelitian pengujian organoleptik terhadap parameter bau dengan lama proses pengeringan tepung ampas tahu menunjukan bahwa hasil analisis sidik ragam (Anova) semua perlakuan memiliki pengaruh yang nyata, hal ini ditujukan pada nilai signifikansi lebih kecil dari 0,005 dan $F_{\text {hitung }}(40,30)$ lebih besar dari $F_{\text {tabel }}(2,27)$ dengan tingkat kepercayaan 95\%. Hasil uji organolpetik bau (aroma) tepung ampas tahu dapat dilihat pada gambar 3.

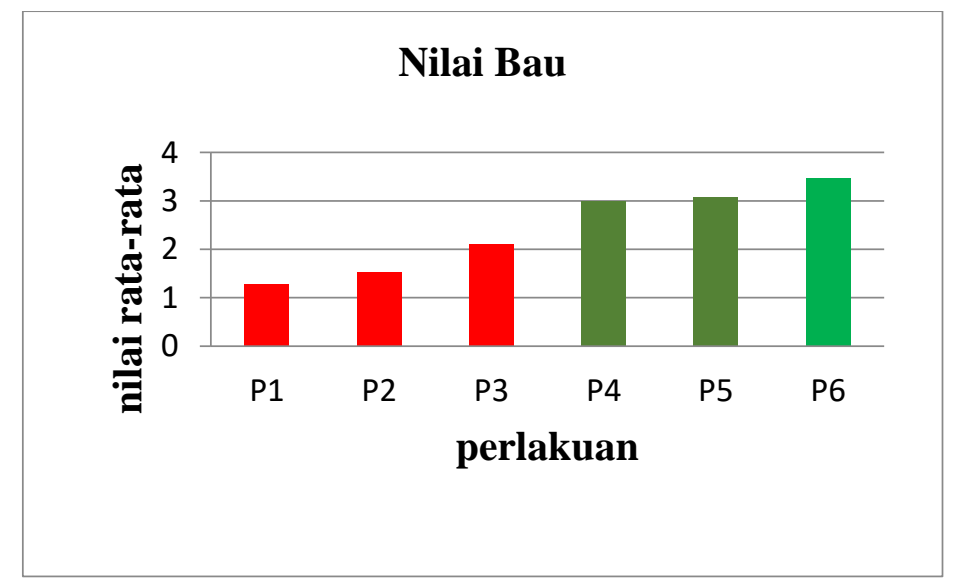

Gambar 3. Histogram hasil uji organoleptik tekstur

Hasil uji untuk parameter bau (aroma) dapat dilihat pada table 3 
Tabel 3. Hasil Uji Lanjut Parameter Bau

\begin{tabular}{ccc}
\hline Perlakuan & Nilai rata-rata & Kriteria \\
\hline P1 & $1,27^{\mathrm{a}}$ & Tengik \\
P2 & $1,53^{\mathrm{a}}$ & Tengik \\
P3 & $2,10^{\mathrm{b}}$ & Tengik \\
P4 & $3,00^{\mathrm{c}}$ & Agak tengik \\
P5 & $3,07^{\mathrm{c}}$ & Agak tengik \\
P6 & $3,47^{\mathrm{d}}$ & Tidak berbau \\
\hline
\end{tabular}

Keterangan : abc superkrip yang diikuti oleh huruf yang tidak sama menunjukan berbeda nyata. $(p<0,05)$

Hasil uji organoleptik untuk parameter bau pada perlakuan P1 (skor 1,27) dengan waktu 15 menit, P2 (skor 1,53) dengan waktu 30 menit dan P3 (skor 2,10) dengan waktu 45 menit masingmasing ketiga perlakuan tersebut menghasilkan bau busuk warna agak kusam disebabkan panelis kurang menerima tepung yang berbau selain penilaian panelis ketiga perlakuan tersebut tepung yang dihasilkan masih mengandung kadar air tinggi. Sedangkan pada perlakuan P6 (skor 3,47) dengan lama pengeringan 90 menit. Pada P6 dengan lama pemanasan 90 menit pada oven mengakibatkan penguapan kadar air yang banyak pada tepung dan penguapan kadar air berperan dalam mempengaruhi aroma (bau) tepung ampas tahu dapat diterima panelis. Selain lama pengeringan aroma yang tidak muncul (bau tengik) yang disebabkan bahan pembuatan tepung dari ampas tahu kering. Ampas tahu kering tidak memiliki aroma (bau tengik)[12]. Aroma khas ampas tahu yang membuat panelis menerima produk dari perlakuan P6 dengan waktu pengeringan 90 menit disebabkan waktu yang digunakan dalam mengeringkan tepung ampas tahu membuat kadar air menjadi berkurang sehingga daya awet tepung semakin baik, memiliki kesegeran sehingga tidak terjadi munculnya bau (tengik). Proses pengeringan akan terjadi penguapan kadar air suatu bahan dan mempengaruhi aroma[13], semakin adanya kenaikan waktu pengeringan akan memberikan pengaruh yang nyata terhadap perpindahan air pada bahan[14].

\section{Rasa}

Hasil uji organolpetik tepung ampas tahu dapat dilihat pada gambar 4

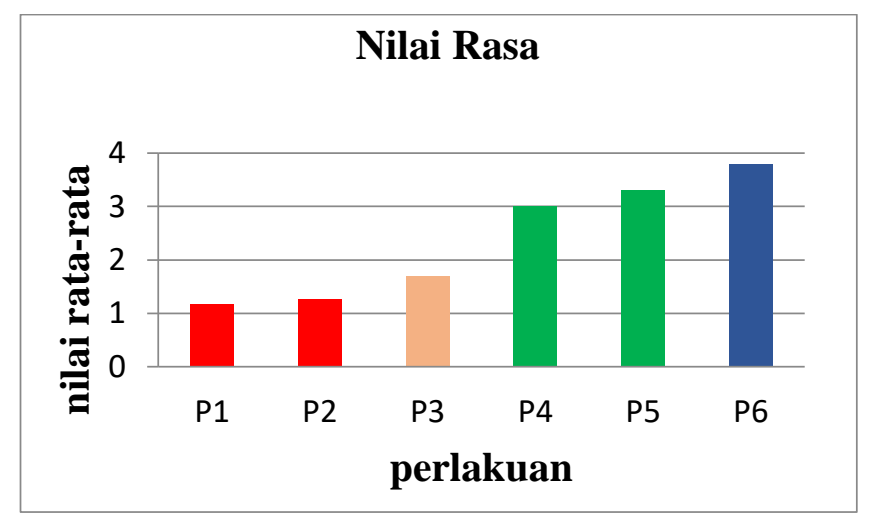

Gambar 4. Histogram hasil uji organoleptik rasa

Tabel 4. Hasil Uji Lanjut Parameter Rasa

\begin{tabular}{lll}
\hline Perlakuan & Nilai rata-rata & Kriteria \\
\hline P1 & $1,17^{\mathrm{a}}$ & Tidak ada khas \\
P2 & $1,27^{\mathrm{a}}$ & Tidak ada khas \\
P3 & $1,70^{\mathrm{b}}$ & Sedikit khas ampas tahu \\
P4 & $3,00^{\mathrm{c}}$ & Ada khas ampas tahu \\
P5 & $3,30^{\mathrm{c}}$ & Ada khas ampas tahu \\
P6 & $3,80^{\mathrm{d}}$ & Banyak khas ampas tahu \\
\hline
\end{tabular}

Keterangan : abc superkrip yang diikuti oleh huruf yang tidak sama menunjukan berbeda nyata. $(p<0,05)$ 
Hasil uji organoleptik parameter rasa pada perlakuan P1 (skor 1,17) memiliki skor terendah karena panelis kurang menerima tepung yang tidak memiliki khas ampas tahu. Sedangkan pada perlakuan P6 (skor 3,80) panelis menerima tepung yang banyak khas ampas tahu. Panelis menerima perlakuan P6 disebabkan rasa tepung ampas tahu yang tawar dan tidak tengik seperti tepung pada umumnya. Rasa tepung ampas tahu tawar yang dipengaruhi banyaknya serat yang tinggi terkadung dari tepung ampas tahu [6]

\section{Tekstur}

Hasil uji organoleptik tepung ampas tahu dapat dilihat pada gambar 5.

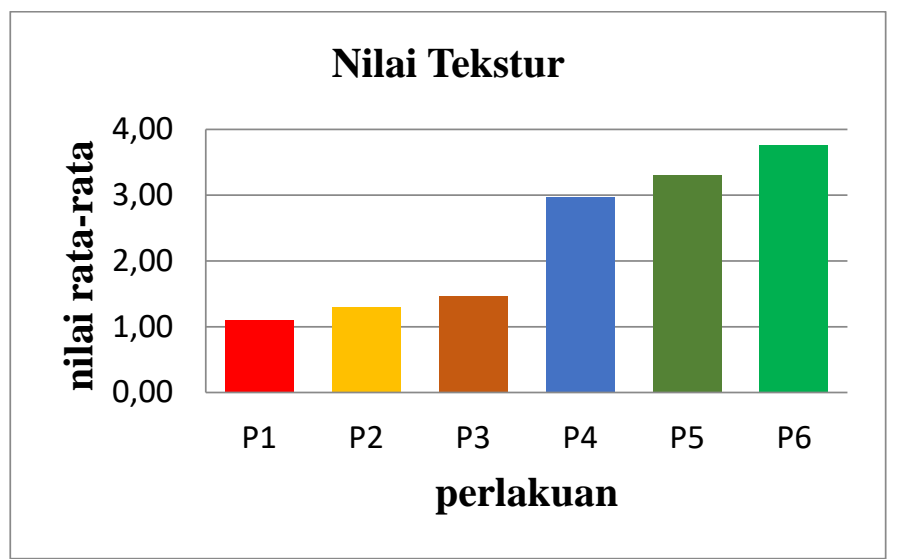

Gambar 5. Histogram hasil uji organoleptik tekstur

Berdasarkan histogram di atas menunjukan P1 dengan nilai rata-rata skor 1,10 (perlakuan 15 menit pengeringan), $\mathrm{P} 2$ dengan nilai rata-rata skor 1,30 (perlakuan 30 menit pengeringan), $\mathrm{P} 3$ dengan nilai rata-rata skor 1,47 (perlakuan 45 menit pengeringan), $\mathrm{P} 4$ dengan nilai rata-rata skor 2,97 (perlakuan 60 menit pengeringan), P5 dengan nilai rata-rata skor 3,30 (perlakuan 75 menit pengeringan) dan P6 dengan nilai rata-rata skor 3,77 (perlakuan 90 menit pengeringan).

Hasil pengujian analisis sidik ragam (Anova) menunjukan hasil semua perlakuan berpengaruh nyata maka dilakukan pengujian uji lanjut yaitu uji Duncan's Multiple Range Test. Adapun hasil uji lanjut untuk parameter tekstur dapat dilihat pada tabel 5

Tabel 5. Hasil Uji Lanjut Parameter Tekstur

\begin{tabular}{|c|c|c|}
\hline Perlakuan & Nilai rata-rata & Kriteria \\
\hline P1 & $1,10^{\mathrm{a}}$ & Menggumpal kasar \\
\hline $\mathrm{P} 2$ & $1,30^{\mathrm{ab}}$ & Menggumpal kasar \\
\hline P3 & $1,47^{\mathrm{b}}$ & Sedikit menggumpal, kasar \\
\hline P4 & $2,97^{\mathrm{c}}$ & Tidak menggumpal, agak kasar \\
\hline P5 & $3,30^{\mathrm{d}}$ & Tidak menggumpal, agak kasar \\
\hline P6 & $3,77^{\mathrm{e}}$ & Tidak menggumpal, halus \\
\hline
\end{tabular}

Hasil uji organoleptik parameter rasa pada perlakuan P1 (skor 1,17) memiliki skor terendah karena panelis kurang menerima tepung yang memiliki tekstur menggumpa kasar. Tekstur pada P1 disebabkan masih banyaknya kandungan air pada tepung sehingga pada proses penggilingan tidak hancur secara merata Sedangkan pada perlakuan P6 (skor 3,80) panelis menerima tepung yang teksturnya tidak menggumpal dan halus. Sifat tidak menggumpal dan halus disebabkan bahan tepung yang kering tidak banyak mengandung kadar air akibat proses pengeringan sehingga mudah dihaluskan selama proses pengeringan. Semakin kadar air rendah dan banyaknya air yang keluar dari suatu bahan pangan akan meningkatkan kehalusan pada produk [15] dan produk (tepung) yang rendah kadar air akan semakin halus selama proses pengeringan 


\section{KESIMPULAN}

Hasil uji organoleptik untuk parameter warna, bau, rasa dan tekstur berpengaruh nyata terhadap karakeristik tepung ampas tahu dengan lama pengeringan yang berbeda. Pada perlakuan P1 menghasilkan warna yang tidak baik secara kenampakan sedangkan perlakuan P6 menghasilkan warna putih kekuningan. Uji parameter bau menghasilkan P1 sampai P3 masingmasing bau tengik dan warna agak kusam sedangkan pada perlakuan P6 dengan lama pengeringan 90 menit tepung ampas tahu yang dihasilakn tidak berbau. Sedangkan pada parameter rasa pada perlakuan P1 tepung yang dihasilkan tidak memiliki rasa khas ampas tahu sedangkan pada perlakuan P4 dan P5 memiliki rasa khas ampas tahu. pada perlakuan P6 tepung yang dihasilkan lebih banyak memiliki rasa khas ampas tahu dari semua perlakuan. Hasil uji organoleptik untuk parameter tekstur berpengaruh nyata terhadap karakteristik tepung ampas tahu dengan lama pengeringan yang berbeda. Pada perlakuan P1 sampai P3 tepung yang dihasilkan memiliki tekstur menggumpal kasar, pada perlakuan P4 dan P5 memiliki tekstur menggumpal kasar sedangkan pada perlakuan P6 tepung yang dihasilkan memiliki tekstur tidak menggumpal dan halus.

\section{DAFTAR PUSTAKA}

[1] I. Widaningrum, "Teknologi Pembuatan Tahu yang Ramah Lingkungan (Bebas Limbah)," J. Dedik., 2015.

[2] H. Seftiono, "Perubahan Sifat Fisiko Kimia Protein Selama Perubahan Sifat Fisiko Kimia Protein Selama," vol. 3, no. 1, pp. 85-92, 2017, [Online]. Available: http://trilogi.ac.id/journal/ks/index.php/jks/article/view/329/218.

[3] A. Herlambang, "Teknologi Pengolahan Limbah Cair Industri Tahu," Jai, 2002, doi: 10.1134/S0006350909040186.

[4] I. Yustina and F. Abadi, "Potensi tepung dari ampas industri pengolahan kedelai sebagai bahan pangan," Semin. Nas. Kedaulatan Pangan dan Energi, 2012.

[5] "PENGARUH PENGGUNAAN TEPUNG AMPAS TAHU TERHADAP KARAKTERISTIK KIMIA DAN ORGANOLEPTIK KUE STICK,” Teknol. PANGAN Media Inf. dan Komun. Ilm. Teknol. Pertan., 2017, doi: 10.35891/tp.v8i2.905.

[6] R. Wati, "PENGARUH PENGGUNAAN TEPUNG AMPAS TAHU SEBAGAI KOMPOSIT TERHADAP KUALITAS KUE KERING LIDAH KUCING," Food Sci. Culin. Educ. J., 2013.

[7] R. Purwadi, N. Nicko, and P. Stephanie, "Optimasi temperatur udara pengering dan laju alir umpan pada proses pengeringan ragi roti," J. Tek. Kim. Indones., 2018, doi: 10.5614/jtki.2009.8.1.1.

[8] G. . Puspitasari, Wignyanto, and B. S. . Dewanti, "Pemanfaatan Jamur Tiram Putih (Pleurotus ostreatus) Sebagai Tepung, Kajian Pengaruh Suhu dan Lama Pengeringan.," Penelitian, 2013.

[9] D. H. Nuri Andarwulan, Feri Kusnandar, "Pengelolaan Data Analisis Pangan PEND," Pang4411/Modul 1 1.3, 2018.

[10] N. Erni, K. Kadirman, and R. Fadilah, "PENGARUH SUHU DAN LAMA PENGERINGAN TERHADAP SIFAT KIMIA DANORGANOLEPTIK TEPUNG UMBI TALAS (Colocasia esculenta)," J. Pendidik. Teknol. Pertan., 2018, doi: 10.26858/jptp.v1i1.6223.

[11] S. S. Yuwono and A. Ad, "FORMULASI BERAS ANALOG BERBASIS TEPUNG MOCAF DAN MAIZENA DENGAN PENAMBAHAN CMC DAN TEPUNG AMPAS TAHU," J. Pangan dan Argoindustri, 2015.

[12] E. Handarisari, "EKSPERIMEN PEMBUATAN SUGAR PASTRY DENGAN SUBSTITUSI TEPUNG AMPAS TAHU ( Experiments on Making Sugar Pastry Tofu Flour Substitution )," Pangan dan Gizi, 2010. 
[13] S. Cahyani, T. Tamrin, and H. Hermanto, "Pengaruh Lama dan Suhu Pengeringan Terhadap Karakteristik Organoleptik, Aktivitas Antioksidan dan Kandungan Kimia Tepung Kulit Pisang Ambon (Musa Acuminata Colla),” J. Sains dan Teknol. Pangan, vol. 4, no. 1, pp. 2003-2016, 2019, [Online]. Available: http://ojs.uho.ac.id/index.php/jstp/article/view/5637/4139.

[14] A. Riansyah, A. Supriadi, and R. Nopianti, "PENGARUH PERBEDAAN SUHU DAN WAKTU PENGERINGAN TERHADAP KARAKTERISTIK IKAN ASIN SEPAT SIAM (Trichogaster pectoralis) DENGAN MENGGUNAKAN OVEN," J. FishtecH, 2013, doi: 10.36706/fishtech.v2i1.1103.

[15] C. Ardianto, F. Swastawati, and P. H. Riyadi, "Effect of Different Concentation of Liquid Smoke on Characteristic of Arabushi Eastern Little Tuna (Euthynus affinis)," J. Pengolah. dan Bioteknol. Has. Perikan., 2014. 